\title{
Identification of a component of Drosophila polar granules
}

\author{
BRUCE HAY, LARRY ACKERMAN, SANDRA BARBEL, LILY Y. JAN and YUH NUNG JAN* \\ Howard Hughes Medical Institute, Departments of Physiology and Biochemistry, University of Californta, San Francisco, CA 94143, \\ USA
}

\section{Summary}

Information necessary for the formation of pole cells, precursors of the germ line, is provided maternally and localized to the posterior pole of the Drosophila egg. The maternal origin and posterior localization of polar granules suggest that they may be associated with pole cell determinants. We have generated an antibody (Mab46F11) against polar granules. In oocytes and early embryos, the Mab46F11 antigen is sharply localized to the posterior embryonic pole. In pole cells, it becomes associated with nuclear bodies within, and nuage around, the nucleus. Immunoreactivity remains associated with cells of the germ line throughout the life cycle of both males and females. This antibody recognizes a $72-74 \times 10^{3} M_{r}$ protein and is useful both as a pole cell lineage marker and in biochemical studies of polar granules.

Key words: Drosophila, polar granules, germ line, cytoplasmic determinants, monoclonal antibody.

\section{Introduction}

Asymmetric segregation of cytoplasmic components is observed during the early cleavages of many vertebrate and invertebrate embryos (Davidson, 1986). Although such cytoplasmic localization is often assumed to be developmentally important, with few exceptions (Weeks \& Melton, 1987), little is known about the nature and function of the segregated components or about the mechanism and control of partitioning. One well-known example is the localization of a distinctive germ cytoplasm in early embryos of many organisms; its segregation into germ line cells is associated with their commitment to the germ cell lineage (Beams \& Kessel, 1974; Eddy, 1975). In insects and anuran amphibians, experimental procedures have demonstrated that germ cytoplasm is both necessary (Bounoure, 1934; Buehr \& Blacklar, 1970; Frohnhöfer et al. 1986; Geigy, 1933; JazdowskaZagrodzinska, 1966; Okada et al. 1974; Smith, 1966; Warn, 1975) and sufficient (Illmensee \& Mahowald, 1974; Niki, 1986; Ikenishi et al. 1986) for the initiation of germ line development.

The germ cytoplasm is ultrastructurally distinctive, containing large numbers of electron-dense cytoplasmic organelles without delimiting membranes (polar granules in Drosophila and germinal granules in amphibians) (Balinsky, 1966; Mahowald, 1962, 1968).
These granules are obvious candidates for elements important in germ cell determination because of their localization exclusively in germ cytoplasm. In Drosophila, the recent isolation of maternal-effect gap mutants which lack polar granules and fail to form germ cells (pole cells) lends further support to this hypothesis (Boswell \& Mahowald, 1985; Lehmann \& Nüsslein-Volhard, 1986; Schüpbach \& Wieschaus, 1986). However, the molecular requirements for germ cell determination are unknown. Studies of the molecular nature of polar granules and the mechanisms of their segregation are therefore important for understanding how the fate of germ cells is specified during early development. A fortuitously discovered monoclonal antibody against polar granules, Mab46F11, may be useful for this purpose, as described below.

\section{Materials and methods}

\section{Stocks}

Drosophila melanogaster were raised on standard cornmeal-yeast-agar medium at $25^{\circ} \mathrm{C}$. Normal flies were of Oregon-R (OR) wild-type strain. Balanced stocks of vasa (vas ${ }^{\mathrm{PD} 23}$ ) and pumillio ${ }^{680}$ were kindly provided by Drs $\mathrm{T}$. Schüpbach and E. Wieschaus, Princeton University, and Drs C. Nüsslein-Volhard and R. Lehmann, Max-Planck Institute, Tübingen, respectively. 


\section{Antibody production}

Polyclonal antisera directed against horseradish peroxidase (HRP) stain the nervous system of Drosophila as well as that of other insects (Jan \& Jan, 1982). In an attempt to generate antibodies directed against subpopulations of neurones, a hybridoma fusion and screen for monoclonal antibodies was carried out, in which HRP (Sigma type VI) was used as the immunogen. In the course of screening the clone supernatants on tissue sections, an IgM-secreting clone (designated Mab46F11) was isolated which recognizes cells of the Drosophila germ line. This antibody does not bind HRP and thus the relationship of the antigen recognized to the immunogen is unknown.

\section{Antibody staining}

Embryo collections were done according to Allis et al. (1977). Embryos were kept at $25^{\circ} \mathrm{C}$ and time points were taken at $1 \mathrm{~h}$ intervals. Embryos were processed for fixation, devitellinization and antibody staining as described by Bodmer \& Jan (1987). Mab46F11 culture supernatant was diluted fivefold in blocking buffer $(0.1 \mathrm{M}$-phosphate, $\mathrm{pH} 7 \cdot 5,0.3 \%$ Triton $\mathrm{X}-100,0.3 \%$ sodium deoxycholate, $2 \%$ bovine serum albumin (Miles, fraction $\mathrm{V}$ )) prior to use.

For cryostat sections, embryos or ovaries were fixed as above for $5 \mathrm{~min}$, covered with a drop of OCT compound (Lab Tek products), frozen onto a chuck at $-20^{\circ} \mathrm{C}$ and sectioned at $12 \mu \mathrm{m}$ with a Reichert-Jung 2800 Frigocut. Sections were placed on slides coated with $0.1 \%$ gelatin and fixed for $10 \mathrm{~min}$ in $2 \%$ formaldehyde, $0 \cdot 1 \mathrm{~m}$-phosphate buffer, $\mathrm{pH} 7 \cdot 6$. Slides were processed for antibody staining as above.

For whole-mount staining of larval and adult gonads, the following procedure was adopted. A number of gonads were dissected in Schneider's Drosophila medium (Gibco). Gonads were then placed on a glass slide coated with $0.1 \%$ gelatin and the bulk of the excess solution withdrawn. A second slide similarly coated was then gently lowered down onto the first slide, pressing the tissue between them. The two slides were then placed against a block of dry ice for $5 \mathrm{~min}$. The slides were then split apart with a razor blade and transferred to prechilled acetone $\left(-70^{\circ} \mathrm{C}\right)$ for $5 \mathrm{~min}$, to prechilled methanol $\left(-70^{\circ} \mathrm{C}\right)$ for $3 \mathrm{~min}$, and then through an ethanol series (at room temperature) into $0.1 \mathrm{M}$-phosphate buffer, $\mathrm{pH} 7 \cdot 6$. Slides were processed for antibody staining as above.

Immunoelectron microscopy was carried out as follows. Embryos were dechorionated in bleach: water (1:1), rinsed extensively with water and placed onto double-stick tape. They were then covered with fixative ( $2 \%$ glutaraldehyde, $4 \%$ paraformaldehyde, $15 \%$ picric acid, $0.1 \mathrm{M}$-sodium cacodylate, $\mathrm{pH} 7 \cdot 2-7 \cdot 4)$. The vitelline membrane was ruptured with a glass microelectrode and embryos allowed to fix for $10 \mathrm{~min}$. Embryos were then nudged out of their vitelline membranes with a pair of blunt forceps and fixation allowed to continue for another $30 \mathrm{~min}$. Tissues were dissected under the fixative and incubated similarly. Samples were then rinsed three times with $0 \cdot 1 \mathrm{M}$-sodium cacodylate $\mathrm{pH} 7 \cdot 2-7 \cdot 4$. En bloc staining was performed with $2 \%$ aqueous uranyl acetate for $2 \mathrm{~h}$. A brief water rinse was followed by dehydration in $35 \%, 75 \%$ and $95 \%$ ethanol. The tissue was infiltrated with Lowicryl K4M (Polyscience): ethanol in proportions 1:2, 1:1 and undiluted $\mathrm{K} 4 \mathrm{M}$ for $2 \mathrm{~h}$ each, at room temperature. The initiator was benzoin ethyl ether. Polymerization was effected with a u.v. lamp (model UVG-11, Ultraviolet Products) at $356 \mathrm{~nm}$ for $24-48 \mathrm{~h}$. Immunostaining was carried out as follows. Sections were incubated in water for $1 \mathrm{~min}$, in blocking buffer ( $3 \%$ BSA, $2 \%$ normal goat serum, $0 \cdot 1 \mathrm{~m}$-phosphate buffer, $\mathrm{pH} 7 \cdot 2,0 \cdot 3 \%$ Triton $\mathrm{X}-100,0 \cdot 3 \%$ deoxycholic acid) for $5 \mathrm{~min}$, and with Mab46F11, diluted 1:4 in blocking buffer, for $15 \mathrm{~min}$. Sections were then rinsed in blocking buffer with three changes of $2 \mathrm{~min}$ each, and subsequently in the same buffer with secondary antibody (goat antimouse IgM conjugated with $5 \mathrm{~nm}$ colloidal gold (Jansen)), for $10 \mathrm{~min}$. Grids were then rinsed as above, then three times, for $1 \mathrm{~min}$ each, with water. Sections were then poststained with $2 \%$ aqueous uranyl acetate for $5 \mathrm{~min}$ and rinsed thoroughly with water. Sections were examined and photographed with a Philips 400 transmission electron microscope.

\section{Western blotting}

Protein extracts were prepared from various sources by homogenizing the tissue in a glass/glass homogenizer in approximately 10 vol. of extraction buffer (2.5\% SDS, $0 \cdot 1 \mathrm{M}$-Tris- $\mathrm{HCl}, \mathrm{pH} 6 \cdot 8,10 \mathrm{~mm}$-ethylenediaminetetraacetic acid (EDTA)) to which the protease inhibitors $(100 \mu \mathrm{M}$ benzamidine, $10 \mathrm{~mm}$-sodium bisulphite, $2 \mathrm{~mm}$-phenylmethylsulphonyl fluoride (PMSF), 1 mM-ethyleneglycol-bis-(Baminoethyl ether) $N, N, N^{\prime}, N^{\prime}$-tetraacetic acid (EGTA), $10 \mu \mathrm{M}$-leupeptin, $10 \mu \mathrm{M}$-pepstatin, $100 \mathrm{Ki} . u . \mathrm{ml}^{-1}$ aprotinin) were added just before use. Samples were then boiled for $5 \mathrm{~min}$ and spun at full speed in a microfuge (Eppendorf) for $5 \mathrm{~min}$ to pellet insoluble material. The supernatants were aliquoted and stored at $-80^{\circ} \mathrm{C}$. For SDS-PAGE, equal amounts of sample protein were precipitated with $15 \%$ trichloroacetic acid (TCA) at $4^{\circ} \mathrm{C}$ for $20 \mathrm{~min}$, and then pelleted in a microfuge at full speed at $4^{\circ} \mathrm{C}$. The supernatants were aspirated and the pellets resuspended with acetone at $4^{\circ} \mathrm{C}$. The samples were repelleted as above and the supernatants aspirated. The acetone pellets were then processed for SDS-PAGE under reducing conditions according to Laemmli (1970), and run on $10 \%$ polyacrylamide gels with $4 \%$ stacking gels. Protein was transferred to nitrocellulose (Schleicher \& Schuell, BA85) according to Towbin et al. (1979), using a Biorad transblot cell at $0 \cdot 1 \mathrm{~A}$ for $8-12 \mathrm{~h}$. Nonspecific binding sites were blocked by incubation of filters for $1 \mathrm{~h}$ in blocking buffer $(10 \mathrm{~mm}$ Tris- $\mathrm{HCl} \mathrm{pH} 8 \cdot 0,150 \mathrm{~mm}-\mathrm{NaCl}, 0.05 \%$ Tween-20 and $2 \%$ $\mathrm{BSA}$ ), at $37^{\circ} \mathrm{C}$. Filters were subsequently incubated at room temperature for $1 \mathrm{~h}$ with blocking buffer and Mab46F11 (1:10 dilution of culture supernatant), $1 \mathrm{~h}$ with affinity-purified rabbit anti-mouse IgM antibody (Zymed $1: 1000$ dilution), and $1 \mathrm{~h}$ with alkaline phosphatase-conjugated goat anti-rabbit antibody (Promega Biotec, 1:7500). Three $15 \mathrm{~min}$ washes in blocking buffer followed each antibody incubation. Following a final wash, in blocking buffer without BSA, the alkaline phosphatase reaction product was developed according to the Promega Biotec protocol. 


\section{Embryo fractionation}

To obtain a protein sample enriched for pole cells, a variation of the protocol of Allis et al. (1977) for the isolation of pole cells was adopted, in which Percoll (Pharmacia) was substituted for Renografin-60 as a centrifugation medium. A final crude cell pellet (Allis et al. 1977) was resuspended into $3-5 \mathrm{ml}$ of Chan and Gehring buffer (Chan \& Gehring, 1971) (55 mm- $\mathrm{NaCl}, 40 \mathrm{~mm}-\mathrm{KCl}, 15 \mathrm{~mm}$ $\mathrm{MgSO}_{4}, 5 \mathrm{~mm}-\mathrm{CaCl}_{2}, 20 \mathrm{~mm}$-glucose, $50 \mathrm{~mm}$-sucrose, $10 \mathrm{~mm}$-Tricine, $\mathrm{pH} 7 \cdot 0,1 \mathrm{mg} \mathrm{ml}^{-1} \mathrm{BSA}$ ) minus calcium $\left(\mathrm{C} \& \mathrm{G}-\mathrm{Ca}^{2+}\right)$, and loaded on a Percoll gradient constructed as described below. A $90 \%$ Percoll stock was created by diluting $10 \times \mathrm{C} \& \mathrm{G}-\mathrm{Ca}^{2+} 1: 9$ with $100 \%$ Percoll. This was diluted appropriately with $1 \times \mathrm{C} \& \mathrm{G}-\mathrm{Ca}^{2+}$ to generate $15 \%, 70 \%$ and $80 \%$ working Percoll solutions. A $35 \mathrm{ml} \mathrm{15-70 \%} \mathrm{linear} \mathrm{Percoll} \mathrm{gradient} \mathrm{was} \mathrm{created} \mathrm{over} \mathrm{a}$ $5 \mathrm{ml} 80 \%$ bottom layer in $50 \mathrm{ml}$ Falcon tubes. The gradient was centrifuged at $400 \mathrm{~g}$ for $20 \mathrm{~min}$ in a Sorvall SS34 rotor with the brake off. $2 \mathrm{ml}$ gradient fractions were collected from the top. These were diluted 1:1 with $C \& G$ minus BSA (C\&G - BSA) and spun at $120 \mathrm{~g}$ for $10 \mathrm{~min}$ to pellet the cells. Resuspension and pelleting were repeated twice to remove traces of Percoll. Cells were then resuspended in $500 \mu \mathrm{l}$ of $\mathrm{C} \& \mathrm{G}-\mathrm{BSA}$ and counted using a hemocytometer. Cell-rich fractions were saved. A $100 \mu$ l sample of cells from each fraction was processed as described below for immunocytochemistry, and the rest of the sample processed for Western blotting.

For immunocytochemistry, cells isolated from Percoll gradients were allowed to attach to glass coverslips coated with $100 \mu \mathrm{g} \mathrm{ml}^{-1}$ concanavalin A (Sigma type IV) and $1 \mathrm{mg} \mathrm{ml}^{-1}$ of poly-D-lysine hydrobromide (Sigma, approximate $M_{\mathrm{r}} 345000$ ) for $5 \mathrm{~min}$, fixed in $4 \%$ formaldehyde, $0 \cdot 1 \mathrm{M}$-phosphate buffer, $\mathrm{pH} 7 \cdot 6$, for $15 \mathrm{~min}$, and then processed for antibody staining as above.

\section{Pole cell counts}

Pole cell number and position in whole-mount embryos were recorded at different developmental stages using a Nikon Optiphot microscope equipped with differential interference contrast optics. A Nikon camera lucida was used to outline each labelled cell. Counts were made from these drawings.

\section{Results}

\section{The antigen recognized is associated with polar granules}

Embryogenesis in Drosophila begins with a period of internal nuclear divisions; this is followed by migration of most of these nuclei to the egg periphery where blastoderm formation occurs. In the unfertilized egg and cleavage-stage embryo, cortical cytoplasm at the posterior pole contains large numbers of polar granules, $0.2-0.5 \mu \mathrm{m}$, electron-dense structures (Mahowald, 1962). At the end of the eighth nuclear division (beginning of stage 3; staging is that of Campos-Ortega \& Hartenstein, 1985), several nuclei migrate into this cortex and become incorporated into three to five cytoplasmic buds that protrude from the posterior egg pole. Most polar granules become incorporated into these buds (Counce, 1963; Mahowald, 1968). Subsequently, during stages 3 and 4 , these buds divide twice (Foe \& Alberts, 1983), before 12-32 pole cells pinch off. These cells divide from 0 to 2 times prior to blastoderm formation (Technau \& Campos-Ortega, 1986). Polar granules are segregated into these newly formed pole cells, which also contain large, electron-dense, nuclear structures that are distinct from nucleoli and known as nuclear bodies (Mahowald et al. 1976). Later during embryogenesis, polar granules and nuclear bodies fragment and small bits of electron-dense material (presumably derived from these structures) are found dispersed throughout the cytoplasm. Some of this electron-dense material is associated with the cytoplasmic face of the nuclear envelope and is called nuage (Mahowald, 1971a; Allis et al. 1979). Nuage is also seen in germ line cells in larval and adult stages, and appears to be a germ-line-specific structure.

Staining with Mab46F11 parallels the localization of polar granules, nuclear bodies and nuage. In the unfertilized egg and cleavage-stage embryo, immunoreactivity is confined to a thin cortical cap at the embryonic posterior pole (Fig. 1A). Immunoreactivity subsequently becomes associated with the nuclei that migrate into the posterior pole cortex (Fig. 1B). This localization may involve active sequestration by the nuclei or degradation in the surrounding regions, since cortical internuclear regions are relatively devoid of immunoreactivity. By the time pole cells form, immunoreactivity is almost always localized only to cells with a typical pole cell morphology (Fig. 1C,D).

At the EM level immunocytochemical label is associated with polar granules and nuclear bodies of newly formed pole cells (Fig. 2). Later in embryogenesis immunoreactivity in the pole cell becomes scattered throughout the cytoplasm and associated with nuage (data not shown; nuage-associated label is shown in Fig. 6A, in the adult ovary).

Although material similar to Drosophila polar granules and nuage has been observed in the germ line of a number of species (Beams \& Kessel, 1974; Eddy, 1975), the antibody does not recognize these structures in Xenopus laevis, Caenorhabditis elegans or various other Drosophila species, including the closely related species, $D$. simulans and $D$. mauritiana.

\section{The fate of pole cells during embryogenesis}

In Drosophila roughly twice as many pole cells are initially produced as ultimately become associated with the gonads (Rabinowitz, 1941; Sonnenblick, 
1941; Turner \& Mahowald, 1976; Zalokar \& Erk, 1976; Underwood et al. 1980; Technau \& CamposOrtega, 1986). From experiments in which exogenously labelled pole cells are transplanted to unlabelled embryos, it appears that this reduction involves both pole cells becoming lost and pole cell death during migration to the site of the gonad. There is little or no evidence suggesting pole cells contribute
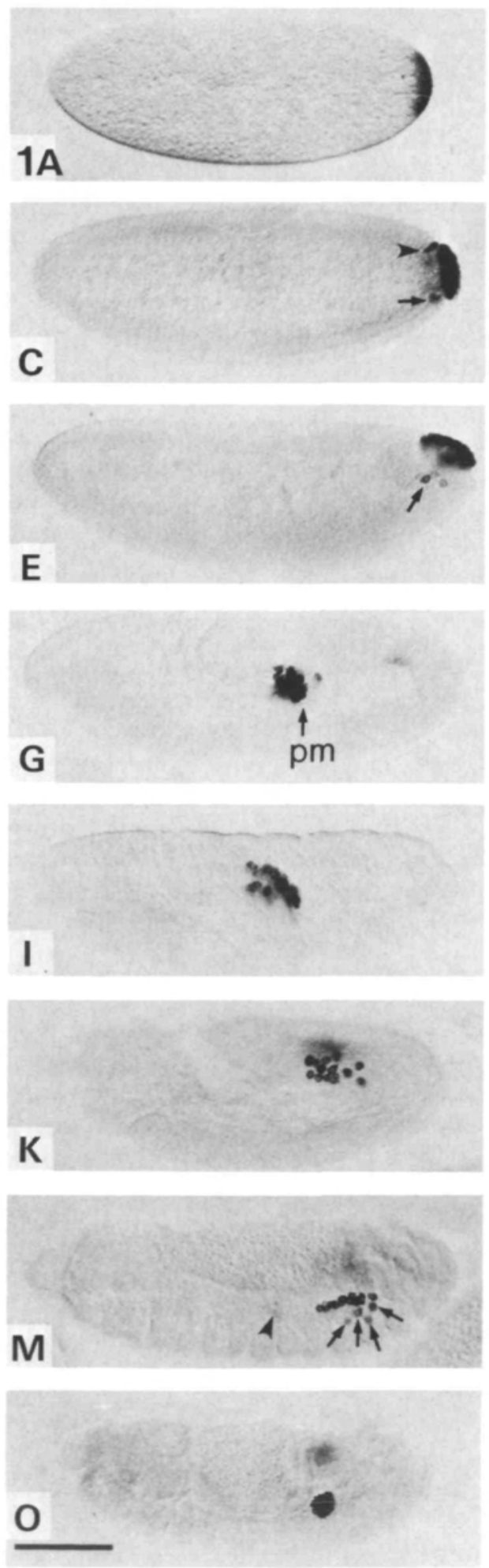

to tissues other than the germ line (Underwood et al. 1980; Technau \& Campos-Ortega, 1986). In order to determine the utility of Mab46F11 as a pole cell lineage marker, we have used this antibody to follow the fate of pole cells and their migrations during embryogenesis. For this purpose, the number of Mab46F11 immunoreactive cells and their distribution between 'lost' and appropriately migrating cell

B
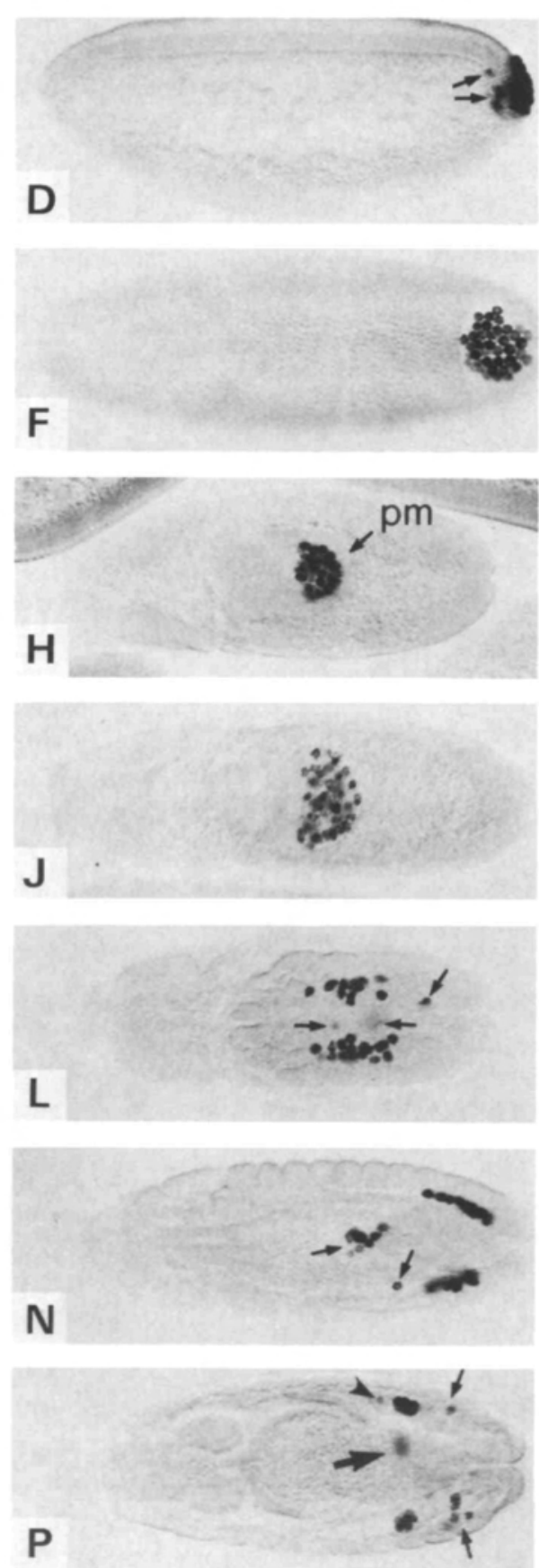
populations, through stage 14 of embryogenesis (by which time the presumptive gonads have formed), was tabulated and plotted as frequency histograms in Fig. 3.

Most of the Mab46F11 immunoreactive cells present at the posterior pole of the embryo by the beginning of gastrulation (stages $6-7)(\bar{X}=41 \pm 0 \cdot 7$; \pm S.E.M.; $n=100$ for each sample; Fig. 3A) have a typical pole cell morphology (Fig. $1 E, F)$ and are found outside the blastoderm. A variable number $(0-8)$ is found lying interdigitated between neighbouring, nonstaining, blastoderm cells or underneath the blastoderm layer, apposed to its inner face but clearly separated from the yolk by the yolk membrane (Fig. 1C, arrowhead; 1D,E, arrows). At the beginning of gastrulation, pole cells are carried dorsally and anteriorly above a plate of about 150 cells (Fig. 1E,F) which forms a sack that encloses the pole cells and carries them inside the embryo during germ band elongation (Fig. 1G,H). At the end of germ band elongation (stage 10), the pole cells leave this sack by passing through the walls of the posterior midgut primordium (Fig. 1I,J). Occasionally a cell appears trapped in the midgut, or between cells of the midgut epithelia; however, the vast majority migrate through without apparent mishap. The average number of immunoreactive cells present during late stage 10 and early stage 11 is $43 \pm 0.5$ (Fig. $3 B$ ).

During early germ band shortening (early stage

Fig. 1. Distribution of the Mab46F11 antigen before pole cell formation and at various stages of pole cell migration during embryogenesis. Optical sections of whole-mount embryos (anterior is to the left and dorsal is uppermost). In E-P, figures on the left are parasagittal sections and those on the right are horizontal sections of similarly staged embryos. (A) Cleavage-stage (stages 1 and 2) embryo. Label is present in a cortical cap at the posterior pole. (B) Stage-3 embryo in the process of forming pole buds. Label becomes concentrated around nuclei and depleted in the cortical regions between nuclei.

(C) Middle of stage 5, during blastoderm formation. A cap of immunoreactive pole cells sits on top of a nonstaining blastoderm. Several cells in the blastoderm layer have taken up Mab46F11 immunoreactive material (arrow). One of these (arrowhead) has blastoderm cell morphology. (D) Stage-6 embryo, following blastoderm formation. Pole cells which are beneath the blastoderm cell layer are apparent (arrows). (E) Parasagittal view of a stage-7 embryo. Note the three labelled cells lying underneath the blastoderm layer (arrow). (F) Horizontal view of embryo similar to that in E. (G) Parasagittal view of a late stage- 8 to early-stage- 9 embryo. Pole cells are found in the posterior midgut pocket (pm). One pole cell is just outside the midgut. $(\mathrm{H})$ Horizontal view of latestage-9 embryo. Some pole cells are beginning to migrate through the midgut. (I) Parasagittal view of a stage-10 embryo. Most pole cells have migrated through the dorsal
12), pole cells become displaced laterally (Fig. $1 \mathrm{~K}, \mathrm{~L}$ ), and a number $(5 \pm 0 \cdot 4$, Fig. $3 \mathrm{C})$ of apparently lost cells is seen (Fig. 1L). The total number of pole cells has also decreased, to $37 \pm 0.7$ (Fig. 3C'). By the end of germ band shortening (early stage 13), most pole cells are closely associated with each other and are contacting mesoderm at the level of the fifth to eighth abdominal segments (A5-A8) (Fig. 1M,N). The total number of labelled cells has decreased further (from $37 \pm 0.7$ to $29 \pm 0 \cdot 4$, Fig. 3C,D). This is reflected in a decrease in the number of appropriately migrating cells (from $32 \pm 0.5$ to $26 \pm 0 \cdot 4$, Fig. 3C,D) as well as in the number of apparently lost pole cells (from $5 \pm 0 \cdot 4$ to $3 \pm 0 \cdot 2$, Fig. $3 \mathrm{C}, \mathrm{D})$. No further reduction is seen through the middle of stage 14 , when the appropriately migrating pole cells have condensed at the level of $\mathrm{A} 5$ and become surrounded by mesoderm (Fig. 1O,P; Fig. 3E, E').

The following general observations are relevant concerning pole cell fate. First, immunoreactive cells that appear lost are found scattered throughout the embryo up to and through hatching. Therefore it is not the case that pole cells that do not reach the gonad invariably die or become incorporated in other tissues, resulting in a loss of expression of the Mab46F11 antigen. Second, weakly staining cells which have a distorted, blebbing morphology and are in the process of degeneration are found in both lost and appropriately migrating cell populations from the

half of the posterior midgut. (J) Horizontal view of a stage-10 embryo with pole cells migrating through the midgut. (K) Early-stage-12 embryo, the first half of germ band shortening. Pole cells are arranged bilaterally, in groups that run from roughly A5 to A8. (L) Dorsal view of embryo during the first half of stage 12 . Pole cells have become arranged bilaterally. Lost cells are present slightly out of the plane of focus (arrows). (M) Almost parasagittal view of an early-stage-13 embryo, the end of germ band shortening. Pole cells are contacting each other and contacting lateral mesoderm at the level of A5 and A6. Labelled cells, displaced but close to the condensing gonad (arrows) and others lost in the yolk (arrowhead) are present. (N) Horizontal view of a stage13 embryo. Pole cells lie in contact with mesoderm at the level of segments A5-A7, roughly. Lost cells are apparent in the yolk and tail region of the embryo (arrows). (O) Almost parasagittal view of a stage-14 embryo. Pole cells have become surrounded and encapsulated by mesoderm at the level of A5. (P) Horizontal view through a stage-14 embryo. Pole cells are clustered at A5. A lost pole cell is present near the forming gonad (arrowhead). Other lost pole cells are present in the yolk (out of the focal plane, large arrow) and along the body wall of more posterior abdominal segments (small arrows). pm, posterior midgut. (Bar, $100 \mu \mathrm{m}$.) 


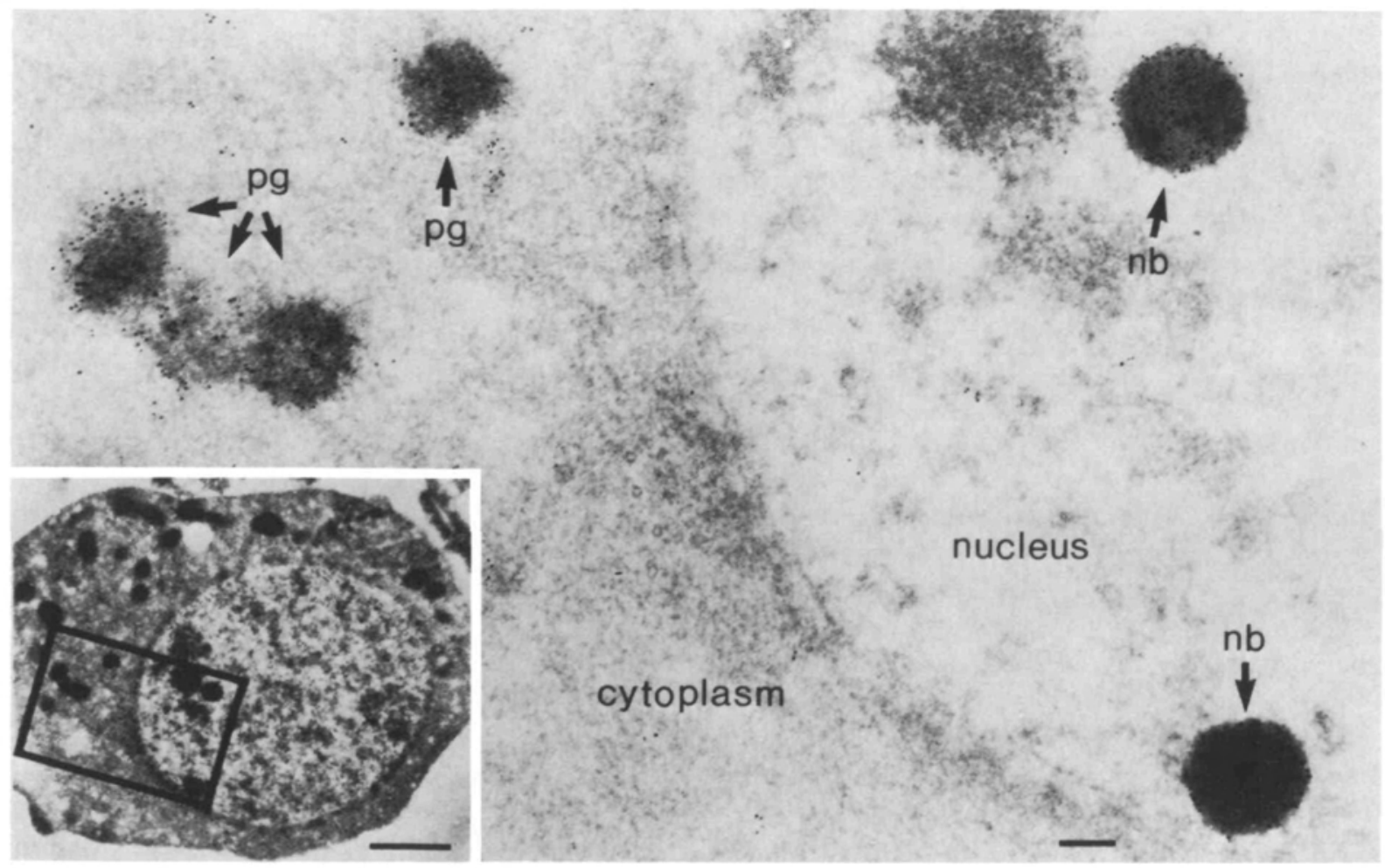

Fig. 2. Immunocytochemical staining of polar granules and nuclear bodies of a pole cell with Mab46F11. A thin section through a pole cell labelled with Mab46F11 and a $5 \mathrm{~nm}$ gold-conjugated second antibody is shown at low magnification in the inset. At higher magnification the boxed portion of the cell is shown. Black dots of $5 \mathrm{~nm}$ gold label are apparent over polar granules (pg) and nuclear bodies (nb) (arrows). Bar, $100 \mathrm{~nm}$; inset, bar, $1 \mu \mathrm{m}$.

end of germ band elongation onward (data not shown). These observations are consistent with the hypothesis that the loss of labelled cells seen during germ band shortening is due to pole cell death, occurring in both lost and appropriately migrating cell populations. By stage 14, we find an average of 14 pole cells per gonad. This number is higher than that reported by others during roughly stages $15-16$, with 5-7 pole cells in gonads of some embryos and 9-13 in gonads of others (Sonnenblick, 1941; Technau \& Campos-Ortega, 1986). This difference in pole cell number suggests that pole cell death continues to occur following initial gonad formation, during stage 14 .

Pole cell fate, as revealed by Mab46F11 staining, generally agrees with conclusions obtained from previous studies (Underwood et al. 1980; Technau \& Campos-Ortega, 1986). However, compared to studies using cell transplantation, immunocytochemical staining with Mab46F11 provides a much simpler and more quantitative method of following pole cells in wild-type and mutant embryos. To illustrate this point, we have carried out Mab46F11 staining of embryos from homozygous pumillio mothers (Fig. 4). The maternally supplied pumillio gene product (located at the embryonic posterior pole) is required for proper abdomen specification; mutant embryos lack variable numbers of abdominal segments. In these embryos, the formation of pole cells and their subsequent migrations during gastrulation are normal (Fig. 4A,B). The behaviour of these cells during germ band shortening is severely disturbed, however. Lost cells are found scattered throughout the stage-13 mutant embryo (Fig. 4C,D), whereas in the wild-type condition they would be aligning themselves along the body wall at the level of A5-A7 (see Fig. 1N). This defect in migration is likely due to an abnormal environment, since functional pole cells can be recovered when pumillio pole cells are transplanted into otherwise sterile host embryos (Lehmann \& Nüsslein-Volhard, 1987).

\section{Continuity of the Mab46F11 antigen in the germ line following embryogenesis}

\section{Adult female germ-line}

Synthesis of polar granule components and assembly and transport of these elements to the future embryonic posterior pole occurs during oogenesis (Mahowald, 1962, 1971a). As a step towards understanding these processes, we have used light and EM immunocytochemistry to examine the cellular and subcellular localization of the Mab46F11 antigen throughout oogenesis. 
Each of the two adult ovaries contains 10-20 parallel egg tubes or ovarioles within which developmental stages of oogenesis are arranged linearly. (See King, 1970, and Mahowald \& Kambysellis, 1978 for reviews.) In Fig. 5A, a whole-mount preparation of part of an ovariole stained with Mab46F11 is shown. At the most anterior end, in the germarium, perinuclear label is present in several large cells, probably stem cells. These cells divide unequally to produce, after each division, another stem cell and a daughter cystoblast. The cystoblast subsequently undergoes four mitotic divisions with incomplete cytokinesis to produce a cluster of 16 cells interconnected by intercellular bridges. These are the smaller labelled cells, located in the posterior germarium (Fig. 5A). One of these 16 cells enters prophase of meiosis 1 and will
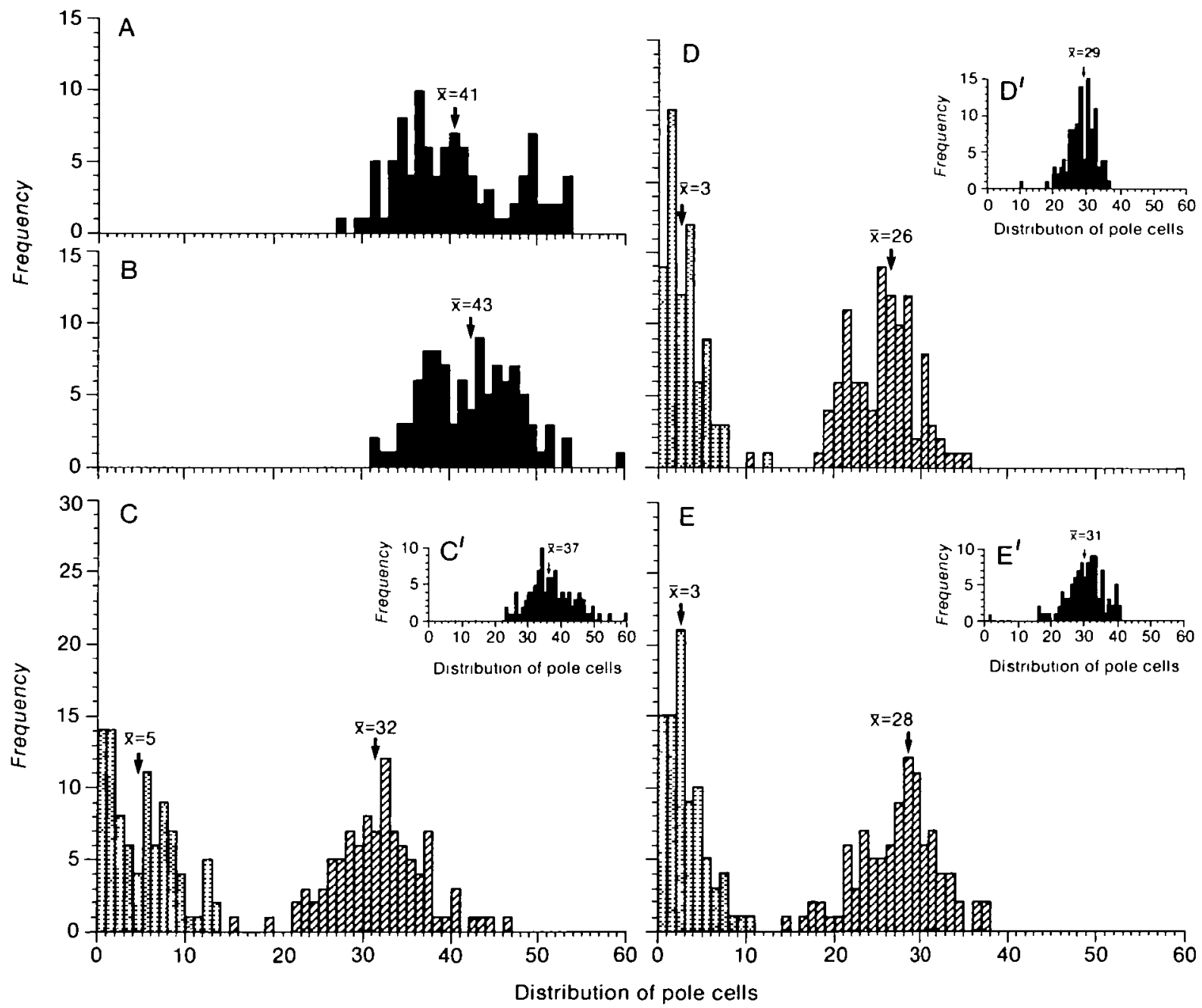

Fig. 3. Number of pole cells and their distribution between appropriately migrating and lost cell populations at different developmental stages. Pole cell counts were carried out as described in the experimental procedures. The total number of pole cells (solid black bars), the number of appropriately migrating pole cells (dashed bars) and the number of apparently lost pole cells (dotted bars) were plotted as frequency histograms, in which the abscissa indicates the number of pole cells in each population in a given embryo, and the ordinate the number of embryos with this number of pole cells. Xs and arrows indicate the mean value for each distribution. (A) Distribution of total pole cell number during stages 6 and 7. (B) Distribution of total pole cell number during late stage 10 and stage 11. (C') Distribution of pole cells into appropriately migrating and lost cell populations during early stage 12 , early germ band shortening. Lost cells at this stage are defined as those labelled cells which do not lie dorsolaterally against the body wall, or which are more than several cell diameters from the main body of pole cells. (C) Distribution of total pole cell numbers during early stage 12, early germ band shortening. (D) Distribution of pole cells into appropriately migrating and lost cell populations at the end of germ band shortening, early stage 13. Cells were scored as lost if they were more than one cell diameter from the main body of pole cells or in a different plane of focus from the main body of pole cells.

$\left(D^{\prime}\right)$ Distribution of total pole cell number at the end of germ band shortening, early stage 13. (E) Distribution of pole cells into appropriately migrating and lost cell populations during stage 14 . Pole cells not contained in the mesodermal sheath that surrounds the germline cells were scored as lost. ( $\left.E^{\prime}\right)$ Distribution of total pole cell number during stage 14. 

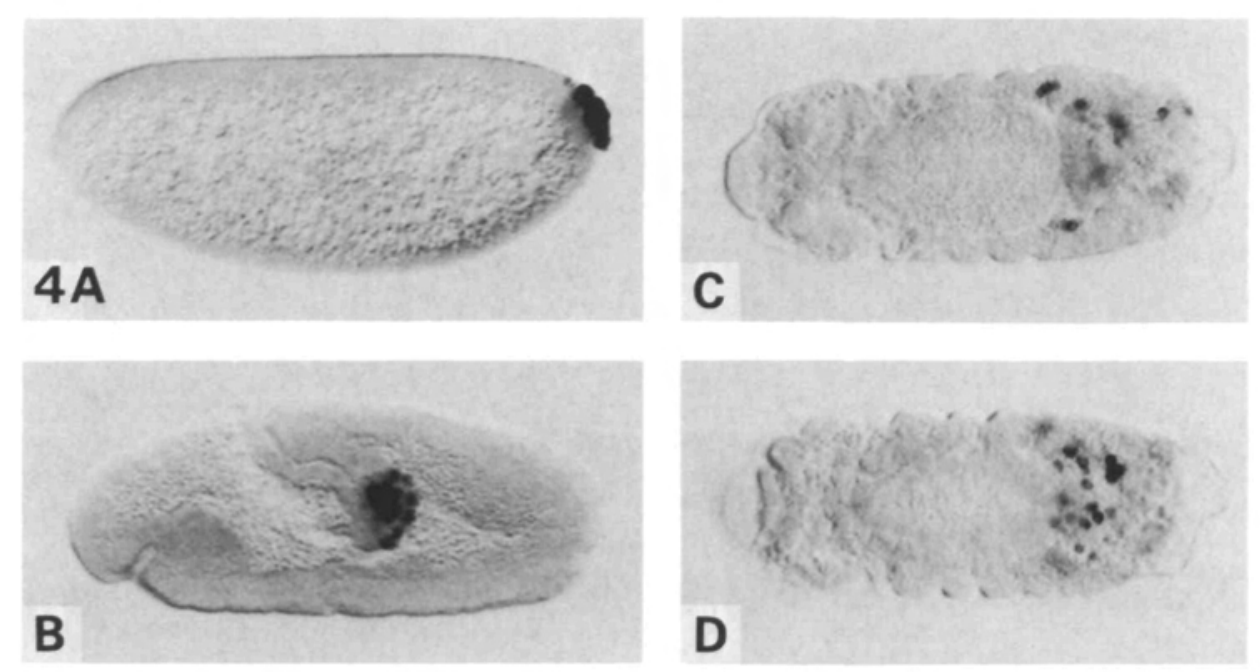

Fig. 4. Stages in pole cell migration in pumillio embryos (embryos from females of genotype pum/pum). Staining of whole-mount embryos with Mab46F11 was carried out as in Fig. 1A. (A) Stage-4 embryo showing Mab46F11 immunoreactive pole cells at the posterior embryonic pole. (B) Stage-10 embryo showing pole cells migrating through the midgut. (C) Horizontal view of stage-13 embryo showing lost pole cells. (D) Different focal plane of embryo shown in $\mathrm{C}$ showing other lost pole cells. (Magnification is the same as in Fig. 1.)

become the oocyte; the other fifteen become nurse cells. During vitellarium stages of oogenesis, in which the bulk of oocyte and nurse cell growth occurs, perinuclear and cytoplasmic label is found in the 15 nurse cells (Fig. 5A,B). Staining is not seen in the oocyte until stage 10 (Fig. 5B, see below). Label is also not apparent in the follicle cells or any other somatically derived tissues of the gonad.

At the EM level, perinuclear label in germ line cells of the germarium (data not shown), and in nurse cells of the vitellarium (Fig. 6A), is found associated with electron-dense clumps of material on the cytoplasmic face of the nuclear envelope. These are the nuage or fibrous bodies previously described in the Drosophila germ line (Counce, 1963; Mahowald, 1971a; Mahowald \& Strassheim, 1970). Label in the nurse cell cytoplasm may reflect the site of synthesis of the antigen.

During stages $10-12$ of vitellogenesis, the nurse cells rapidly decrease in size as they inject their contents into the growing oocyte through intercellular channels at the anterior end of the oocyte. Cytoplasmic mixing rapidly distributes this material throughout the ooplasm (Gutzeit \& Koppa, 1982). Localization of polar granules to the posterior pole of the oocyte takes place during this period, beginning during stage 10 and continuing through stage 13 (Mahowald, 1962, 1971a). At the earliest stage when Mab46F11 immunoreactivity is detectable in the oocyte (around stage 10; Fig. 5B), it is located at the posterior tip of the oocyte and is associated with polar granules (Fig. 6B). By stage 14 (the mature oocyte, Fig. 5C), the number and size of these granules has increased, and they are often found associated with mitochondria (Fig. 6C). Because both polar granules and nurse cell nuage label with Mab46F11, our data support the hypothesis that polar granules may derive from the nuage (Mahowald, 1971a). Since materials from nurse cells enter the oocyte at its anterior end and are mixed rather thoroughly by the swirling movements in the oocyte, the rapid localization of the Mab46F11 antigen to the posterior tip of the oocyte suggests that specific targeting mechanisms are required for this localization.

\section{Adult male germ line}

Synthesis of the Mab46F11 antigen by nurse cells during oogenesis is consistent with a postulated role of the antigen as a component of polar granules, structures important in early germ line determination. Synthesis in the adult male germ line, however, would suggest that this antigen plays additional roles in germ line function. We have carried out immunocytochemical staining with Mab46F11 to address this possibility.

Fig. 5D shows the apical half of a whole-mount testis stained with Mab46F11. Small cells near the apex are germ line stem cells and their offspring the cyst progenitor cells. Cyst progenitors divide mitotically four times to produce a cluster of 16 primary spermatocytes. (See Lindley \& Tokuyasu, 1980 for a detailed review of spermatogenesis.) Perinuclear label is present in each of these cell types (Fig. 5D). One or more large dots of label are also seen in the cytoplasm or associated with the nuclear envelope (Fig. 5D, arrow). These are probably the dense cytoplasmic masses described by Kessel (1981) (see 

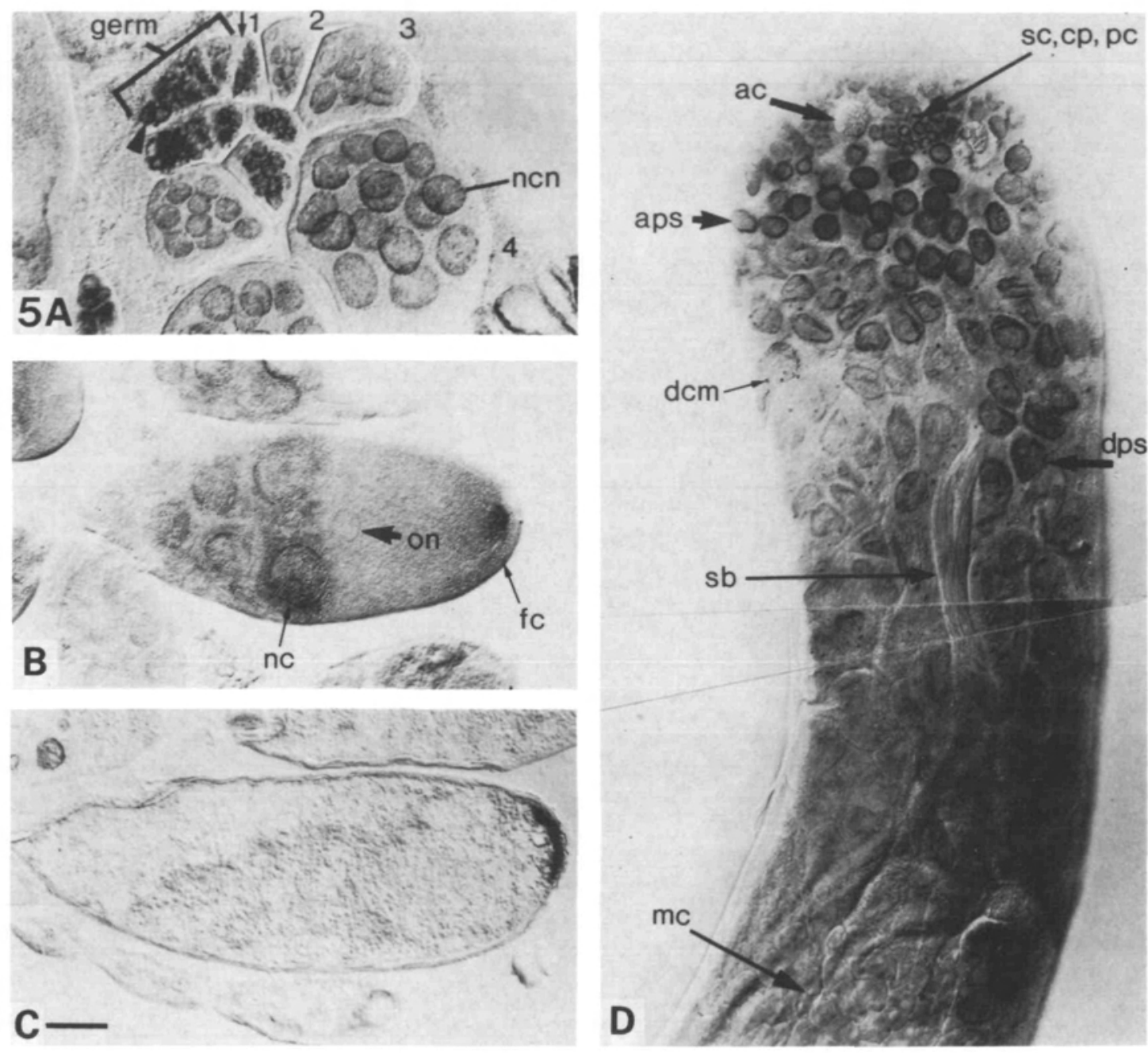

Fig. 5. Distribution of Mab46F11 immunoreactivity during stages of oogenesis and in the adult testis. (A) Whole-mount preparation of an ovariole showing early stages of oogenesis, including the germarium and early stages of the vitellarium. The germarium (germ) is in the upper left. Later vitellariam stages are found in a clockwise direction. A second length of ovariole, also showing germarium and vitellarium stages, lies directly against the inner radius of the ovariole to be described. In the anterior germarium large cells with perinuclear label are found (arrowhead). These are likely germ line stem cells. More posterior, to the right, are a number of smaller labelled cells. These are the clusters of $2,4,8$ or 16 cystocyte cells that derive from the mitotic divisions of the primary cystocyte (cystoblast) in the anterior germarium. In the most posterior germarium, labelled cells are surrounded by nonstaining prefollicle cells (arrow). In the vitellarium-stage egg chambers, labelled 1-4, localized label is confined to the nuclear envelope of nurse cells (ncn). This is particularly clear in the egg chamber labelled 4, in which 15 labelled nuclear envelopes can be seen. Diffuse label is present in the nurse cell cytoplasm. The nonstaining oocyte nucleus is not visible. (B) Whole-mount stage-10 egg chamber labelled with Mab46F11. The posterior pole of the oocyte is to the right. Nurse cells (nc) show perinuclear and diffuse cytoplasmic label. In the oocyte, localized label is restricted to a thin cortical band at the posterior pole. Note that label is not associated with the follicle cells (fc) immediately apposing the posterior pole of the oocyte. The oocyte nucleus (on) is visible in the anterior oocyte, but not stained. (C) Cryostat section through a mature stage-14 oocyte. Label is localized to a dense cortical band at the oocyte posterior pole. (D) Whole-mount preparation of the tip of an adult testis stained with Mab46F11. The nonstaining apical cell cluster (ac) sits near the apical tip of the testis. The small cells with perinuclear label that surround it are probably stem cells (sc), cyst progenitor cells (cp), proliferating cysts (pc), and apical primary spermatocytes (aps). In these cells, large cytoplasmic or perinuclear dots of label are also usually observed. These are probably dense cytoplasmic masses (dcm) (see text). In later stage distal primary spermatocytes (dps), label becomes less distinct around the nucleus. By the time spermatocytes have begun meiosis (mc, meiotic cell), label is not detectable in germ line cells. Part of a nonstaining mature sperm bundle (sb) is visible in this optical plane. (Fig. 5A-D, bar, $200 \mu \mathrm{m}$.) 

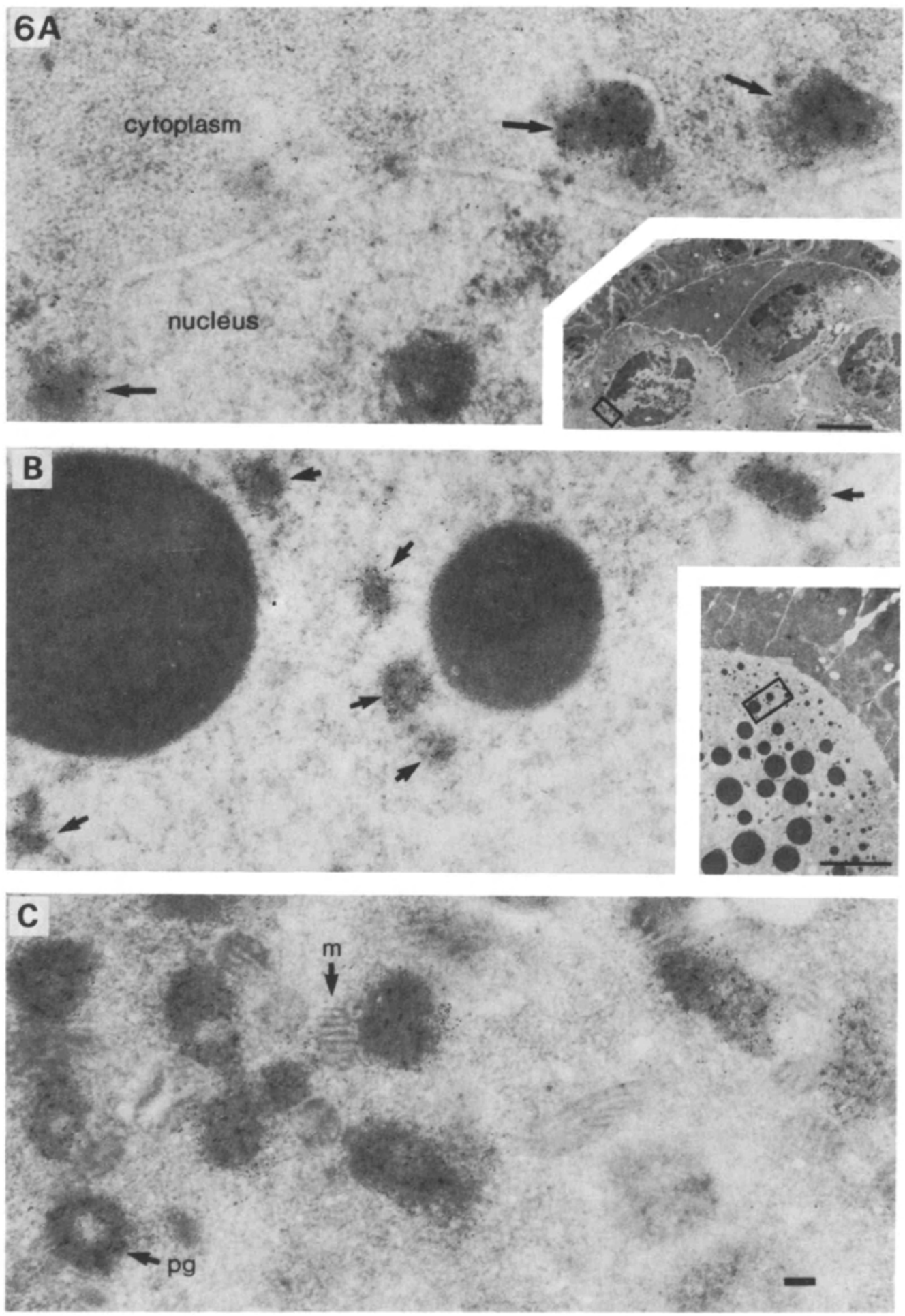

Fig. 6. Ultrastructural localization of the Mab46F11 antigen during oogenesis. (A) The inset shows a section through a stage- 3 or -4 egg chamber. Nurse cells and the follicle cells that overlay them are apparent. The boxed region of a nurse cell is shown at higher magnification. Here label can be seen over electron-dense clumps of material (nuage) along the cytoplasmic face of the nuclear envelope (arrows). (B) The inset shows the posterior pole of a stage-10 oocyte. Numerous yolk bodies are present in the oocyte cytoplasm. In the upper right are follicle cells. The boxed region is shown at higher magnification. Label is associated with polar granules (arrows), somewhat smaller and more irregular in shape than those in the mature oocyte, shown in C. (C) High magnification view of a thin section of the posterior pole of a stage-14, mature, oocyte. Label is found over polar granules (pg), many of which are associated with mitochondria (m). Many polar granules show an electron-lucid core. (Fig. $6 \mathrm{~A}-\mathrm{C}, \mathrm{bar}, 100 \mathrm{~nm}$; insets, bar, $200 \mu \mathrm{m}$.) 

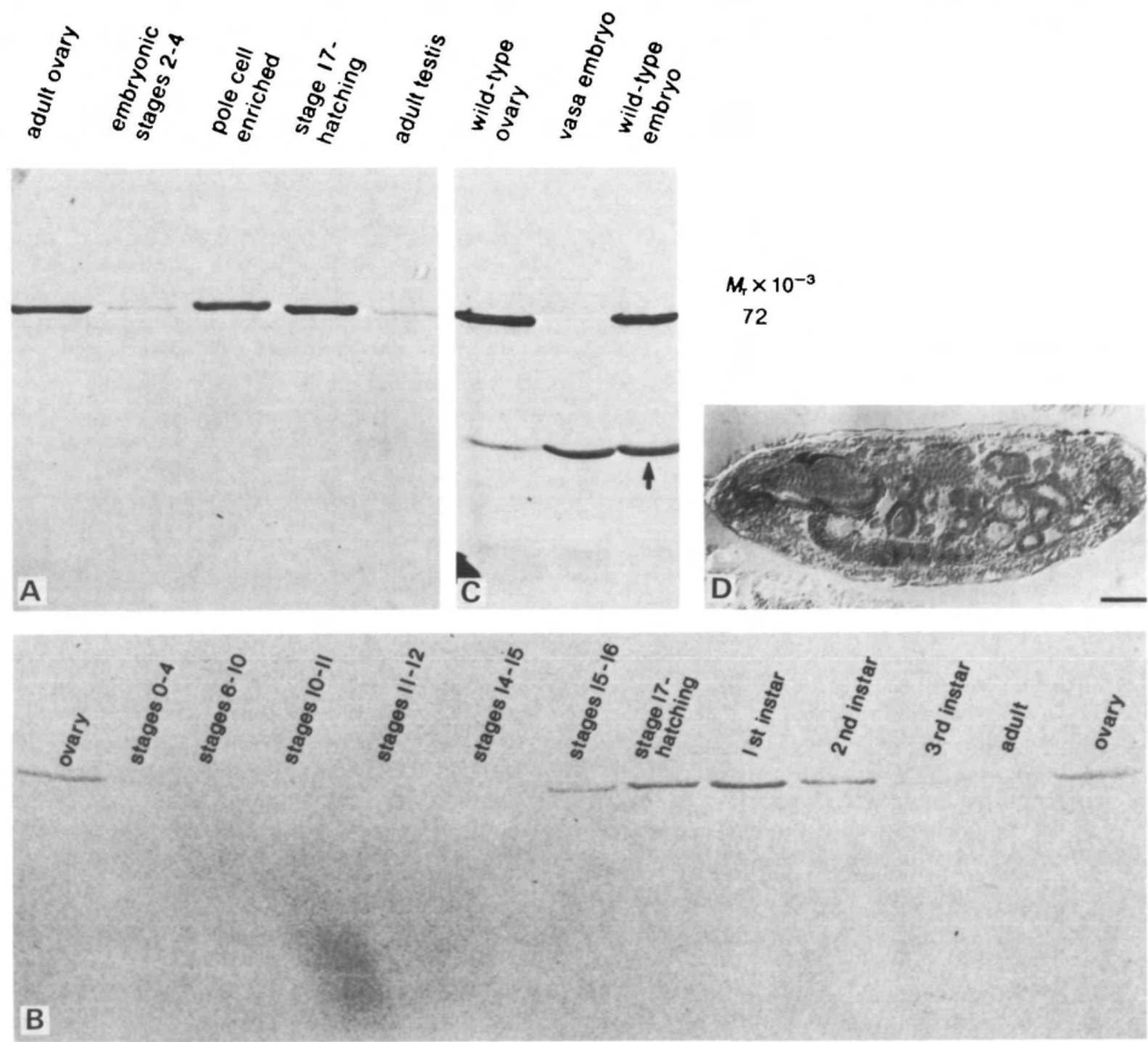

Fig. 7. Identification of the Mab46F11 antigen on Western blots of various Drosophila tissue and developmental life stages. Equal amounts of protein were loaded onto the corresponding gel lanes of each blot. (A) Western blot of tissues and cell populations (see Methods) which are reactive immunocytochemically with Mab46F11. The intensity of the $72-74 \times 10^{3} M_{\mathrm{r}}$ band seen is roughly correlated with the abundance of Mab46F11 immunoreactivity seen

immunocytochemically (see text for details). (B) A developmental time course Western blot containing total protein from various stages of the Drosophila life cycle, as described in the Methods. The adults lane contained equal amounts of protein from males and females from which the gonads had been removed prior to homogenization. (C) Mab46F11 Western blot of wild-type ovary, stage -0 to -3 embryos from homozygous vasa mothers, and stage- 0 to -3 embryos from wild-type mothers. No $72-74 \times 10^{3} M_{\mathrm{r}}$ immunoreactivity is present in the vasa lane. The $45 \times 10^{3} M_{\mathrm{r}}$ band in this blot (arrow) is one of the yolk polypeptides and only appears on prolonged development of the alkaline phosphatase reaction product. (D) Cryostat section of a late-stage embryo labelled with Mab46F11 as described in the Methods. Label is present in nuclei of many cells. Bar, $200 \mu \mathrm{m}$.

Discussion). More distal to these stages, larger maturing spermatocytes are seen. Perinuclear and punctate staining are detectable until about the time spermatocytes enter meiosis. At the EM level, Mab46F11 label in germ line cells of the testis is primarily found over perinuclear, electron-dense structures (data not shown), similar to those labelled in the nurse cells of the ovary (Fig. 6A). The significance of antigen localization to these structures will be returned to in the Discussion.

\section{Nuclear Mab46F11 immunoreactivity}

During late embryogenesis (stage 16 onwards) and during larval life, a general nuclear staining is apparent in essentially all cell types (Fig. 7D), in addition 
to the germ line staining seen with Mab46F11. Similar staining is not seen with second antibody alone or with several other mouse IgM monoclonals used (data not shown). Although it persists throughout larval stages, this staining becomes undetectable in adult somatic tissues (cf. somatic cells of ovary in Fig. 5).

\section{The antigen recognized by Mab46F11 is a 72-} $74 \times 10^{3} \mathrm{M}_{\text {r protein }}$

We have carried out Western blotting with Mab46F11 to identify the antigen recognized by this antibody. Each of the tissues that label immunocytochemically with Mab46F11 contains an immunoreactive $72-74 \times 10^{3} M_{\mathrm{r}}$ protein (Fig. 7A). The intensity of this band on Western blot is roughly correlated with the abundance of the Mab46F11 antigen seen immunocytochemically. Thus, stage- 2 to -4 embryos show a weak immunoreactive band. This band is much more prominent in the lanes containing total protein from adult ovaries or a fraction enriched (roughly 10 -fold) for pole cells from stage- 2 to -5 embryos. A similar band is also present in protein from adult testis.

If the $72-74 \times 10^{3} M_{\mathrm{r}}$ protein is in fact a component of polar granules, it should be absent in mutant embryos which are missing polar granules. One mutant which displays such a phenotype is the maternal-effect mutant vasa (Schüpbach \& Wieschaus, 1986). Embryos from homozygous mutant mothers lack detectable polar granules and fail to make pole cells (Schüpbach \& Wieschaus, 1986). They also lack detectable Mab46F11 antigen immunocytochemically (Hay et al. unpublished data). Fig. 7C shows that these embryos contain no detectable immunoreactive protein, even following prolonged development of the alkaline phosphatase reaction product. The $45 \times 10^{3} M_{\mathrm{r}}$ band in wild-type as well as mutant embryos is one of the yolk polypeptides, major constituents of the early embryo. This band only appears following prolonged exposure and is also present in control experiments using other mouse IgM monoclonal antibodies (data not shown). Thus it is likely the $72-74 \times 10^{3} M_{\mathrm{r}}$ protein from early embryos is associated with polar granules.

Previous studies by Waring et al. (1978) revealed a single major protein species of $95 \times 10^{3} M_{\mathrm{r}}$ enriched for in pole-cell-enriched cell populations. A band of approximately $70 \times 10^{3} M_{\mathrm{r}}$ also appears as a fairly major component of the various fractions (Waring et al. 1978). The relation between this band and the Mab46F11 antigen is not clear. However, of the various tissues and fractions we have examined, the $72-74 \times 10^{3} M_{\mathrm{r}}$ antigen does not comigrate with any major protein species detectable with staining by Coomassie blue. Neither have we detected any immunoreactivity associated with proteins of higher mol- cular weight, even when special attention was paid to avoid possible degradation.

Total protein from late (stage 16 and 17) wild-type embryos (Fig. 7A) (and from homozygous vasa embryos derived from homozygous vasa mothers), has a large amount of an immunoreactive protein. This cannot be accounted for by an increase in the germline-associated antigen, due to gonad growth, but may be due to the nuclear staining of somatic tissues that is well developed by this time (Fig. 7D). Furthermore, the level of the nuclear staining at different stages of the life cycle correlates well with that of the immunoreactive $72-74 \times 10^{3} M_{\mathrm{r}}$ band (Fig. 7B). This band is found at low levels in early embryos. A large increase is apparent by stage 16 , when nuclear staining appears. During the second and third larval instars, the intensity of the $72-74 \times 10^{3} M_{\mathrm{r}}$ immunoreactive band decreases. In adults with gonads removed, there is even less immunoreactive protein, which corresponds to the lack of detectable nuclear staining in adult somatic tissues. The $72-74 \times 10^{3} M_{\mathrm{r}}$ protein identified as a component of polar granules comigrates with the protein associated with somatic nuclei. Whether these are the same protein remains to be determined.

\section{Discussion}

Polar granules are localized to the posterior pole of mature oocytes and early embryos of Drosophila and may be associated with determinants of germ line cells (Illmensee \& Mahowald, 1974). We have isolated a monoclonal antibody, Mab46F11, that recognizes a component of polar granules. This antibody labels germ cells throughout the lifecycle of the fly. Using this antibody, we have made the following observations. (1) The rapid rate at which the Mab46F11 antigen is transported from anteriorly located nurse cells to a thin cortical cap at the posterior end of the oocyte suggests the presence of a specific and effective targeting machinery. (2) The association of this antigen with nuclei in the pole buds of cleavage-stage embryos and its clearing from the internuclear cortical regions raise the possibility that it may be actively sequestered. Likely candidates for this sequestration may include cytoskeletal components that show distinctive patterns of distribution at these early stages (Warn et al. 1985; Karr \& Alberts, 1986). (3) Germ-line-specific structures, including polar granules, nuclear bodies, nuage and dense cytoplasmic masses, are related biochemically because they all contain the Mab46F11 antigen. (4) The Mab46F11 antigen appears as a $72-74 \times 10^{3} M_{\mathrm{r}}$ protein on Western blots. This study suggests that the Mab46F11 antibody may be used for further bio- 
hemical characterizations of the components of polar granules. In addition, this antibody serves as a faithful marker for pole cells throughout embryogenesis. Discussions of some of these points are presented below.

\section{The number and fate of pole cells}

In Drosophila and other Dipterans, many more pole cells are formed than are found in the gonads (Rabinowitz, 1941; Sonnenblick, 1941). This has suggested that pole cells may contribute to tissues other than the germ line (Poulson \& Waterhouse, 1960). However, recent transplantation experiments using $\left[{ }^{3} \mathrm{H}\right]$ thymidine or HRP-labelled pole cells have found no evidence for pole cell incorporation into other tissues (Underwood et al. 1980; Technau \& Campos-Ortega, 1986) and suggest instead that unaccounted cells may have got lost and/or died. Consistent with these observations, we find that two major causes of the low number of pole cells found in the embryonic gonad are (1) pole cells becoming lost, primarily during germ band shortening and (2) pole cell death, occurring in both the lost and appropriately migrating populations, also primarily during germ band shortening.

In pole cell transplantation experiments, in which large numbers of labelled pole cells are transplanted into the posterior pole of an unlabelled blastoderm embryo, the final number of pole cells in the gonads is similar to that of an uninjected embryo $(\bar{X}=9)$. This has suggested that there is regulation of the final number of pole cells in the gonad, with an upper limit of about 13 pole cells per gonad at about stage 16 (Technau \& Campos-Ortega, 1986). Our finding of an average of 14 labelled cells per gonad during stage 14 suggests that some of this regulation may occur following gonad formation, during stages 15-16.

This antibody should prove useful in examining aspects of postembryonic germ cell behaviour since it recognizes premeiotic germ cells throughout the fly lifecycle. It should also greatly facilitate study of the fate of pole cells in embryos in which maintenance of the germ line, following cell formation, is affected (Engstrom et al. 1982; Oliver et al. 1987; Togashi et al. 1986).

\section{Association of the Mab46F11 antigen with germ-line- specific structures}

Polar granules, nuclear bodies, nuage and dense cytoplasmic masses are germline-specific structures. The observations that these structures are all recognized by Mab46F11 and that tissues in which they are found show a common immunoreactive $72-74 \times 10^{3} M_{\mathrm{r}}$ protein on Western blotting indicate they are biochemically related. The fact that similar structures are found in the definitive germ line of phylogenetically distant groups, including other dipterous insects (Mahowald \& Boswell, 1983), nematodes (Strome \& Wood, 1982), amphibians (Smith et al. 1983) and mammals (Eddy \& Hahnel, 1983), suggests that they are important for some fundamental aspect of germ cell life. The function of any of these structures is unknown. It is perhaps relevant, however, to note that in Drosophila polar granules (in oocytes and early embryos) and dense cytoplasmic masses (in spermatocytes) have been demonstrated to contain RNA, and are present at stages when mRNA storage for later use is likely to be important . (Mahowald, 1971b; Kessel, 1981). Thus, it seems plausible, though there is no direct evidence, that these structures store RNA necessary for the determination of germ line cells in the early embryo and for spermatid formation in the testis, respectively.

If polar granules are directly involved in pole cell formation and germ line determination, it should be possible to isolate mutants that lack polar granules and which fail to form pole cells. Such mutants, members of the grandchildless-knirps class of maternal-effect mutations, have been isolated in Drosophila (tudor, Boswell \& Mahowald, 1985; vasa, valois, staufen, Schüpbach \& Wieschaus, 1986; oskar, Lehmann \& Nüsslein-Volhard, 1986). Embryos derived from females homozygous for mutations at these loci lack a germ cytoplasm that contains polar granules and they fail to form pole cells. In addition, however, embryos show deletions of a variable number of abdominal segments, and may exhibit head defects or incomplete blastoderm cellularization, depending on the allele. The absence of this germ cytoplasm appears closely associated with the loss of pole cells and not with deletions of abdominal segments since, in the case of tudor and oskar, the abdominal segmentation and pole cell phenotypes are separable (Boswell \& Mahowald, 1985; Lehmann \& Nüsslein-Volhard, 1986). Similarly, in mutants showing a bicaudal phenotype (a mirror-image duplication of the posterior abdomen at the anterior end) the transformed anterior end lacks polar plasm and does not form pole cells (Bull, 1966; Nüsslein-Volhard, 1977; Mohler \& Wieschaus, 1985). The above grandchildless mutations thus seem most likely to be due to defects in shared elements necessary for the synthesis, packaging, transport or localization of abdomen and pole cell determinants. Indeed, Mab46F11 staining has revealed defects in these processes in the above mutants (Hay et al. unpublished data).

The most direct way of addressing whether polar granules are necessary and sufficient elements for pole cell formation is to isolate them and their constituents from oocytes or preblastoderm embryos (when polar plasm is competent for nuclear induction), for biochemical and genetic analysis. A step in 
this direction is the identification of a $72-74 \times 10^{3} M_{\mathrm{r}}$ protein as a likely component of polar granules, nuclear bodies and nuage. If, based on this association, Mab46F11 can be used to purify polar granules for further molecular characterization of their protein and RNA components, it may be possible to test critically polar granule function in the early embryo.

We would like to thank T. Schüpbach and E. Wieschaus for sending us the vasa ${ }^{\mathrm{PD} 23}$ stock, and $\mathrm{R}$. Lehmann and $\mathrm{C}$. Nüsslein-Volhard for sending us the pumillio ${ }^{680}$ stock. We also thank T. Kornberg for use of his fly cage facility. We especially thank $K$. Logan for help analysing the data concerning pole cell number, E. Bier, K. Logan, K. Neugebauer, and T. Schwarz for their valuable comments on the manuscript and Ms L. Schulte for help in preparing the manuscript. This work was supported by $\mathrm{NIH}$ and HHMI grants to L.Y.J. and Y.N.J. B.H. was supported by an NIH predoctoral training grant. L.Y.J. and Y.N.J. are HHMI investigators.

\section{References}

Allis, C. D., Underwood, E. M., Coulter, J. H. \& Mahowald, A. P. (1979). Pole cells of Drosophila melanogaster in culture. Normal metabolism, ultrastructure, and functional capabilities. Devl Biol. 69, 451-465.

Allis, C. D., Waring, G. L. \& Mahowald, A. P. (1977). Mass isolation of pole cells from Drosophila melanogaster. Devl Biol. 56, 372-381.

Balinsky, B. I. (1966). Changes in the ultrastructure of amphibian eggs following fertilization. Acta Embryol. Morph. exp. 9, 132-154.

Beams, H. W. \& Kessel, R. G. (1974). The problem of germ cell determinants. Int. Rev. Cytol. 39, 413-479.

BoDmer, R. \& JAN, Y. N. (1987). Morphological differentiation of the embryonic peripheral neurons in Drosophila. Wilhelm Roux's Arch. devl Biol. 196, 69-77.

Boswell, R. E. \& Mahowald, A. P. (1985). tudor, a gene required for assembly of the germ plasm in Drosophila melanogaster. Cell 43, 97-104.

Bounoure, L. (1934). Recherches, sur la lignée germinale chez la Grenouille rousse aux premiers stades du développement. Annales des Sciences Naturalles, 10th series. 17, 67-248.

Buehr, M. L. \& Blacklar, A. W. (1970). Sterility and partial sterility in the South African clawed toad following the pricking of the egg. J. Embryol. exp. Morph. 23, 375-484.

Bull, A. L. (1966). Bicaudal, a genetic factor which affects the polarity of the embryo in Drosophila melanogaster. J. exp. Zool. 161, 221-242.

Campos-Ortega, J. A. \& Hartenstein, V. C. (1985). The Embryonic Development of Drosophila melanogaster. New York: Springer-Verlag.

Chan, L. N. \& Gehring, W. J. (1971). Determination of blastoderm cells in Drosophila melanogaster. $J$. Embryol. exp. Morph. 33, 789-801.
CouncE, S. J. (1963). Developmental morphology of polar granules in Drosophila, including observations on pole cell behavior and distribution during embryogenesis. J. Morph. 112, 129-145.

Davidson, E. (1986). Gene Activity in Early Development. New York: Academic Press.

EdDy, E. M. (1975). Germ plasm and the differentiation of the germ cell line. Int. Rev. Cyt. 43, 229-280.

Eddy, E. M. \& Hahnel, A. C. (1983). Establishment of the germ cell line in mammals. In Current Problems in Germ Cell Differentiation (ed. A. McLaren \& C. C. Wylie), pp. 41-69. New York: Cambridge University Press.

Engstrom, E., Coulton, J. H., Underwood, E. M. \& Mahowald, A. P. (1982). Developmental lesions in the agametic mutant of Drosophila melanogaster. Devl Biol. 91, 163-170.

Foe, V. E. \& Alberts, B. M. (1983). Studies of nuclear and cytoplasmic behavior during the five mitotic cycles that precede gastrulation in Drosophila embryogenesis. J. Cell Sci. 61, 31-70.

Frohnhōfer, H. G., LehmanN, R. \& NüSSLeinVOLHARD, C. (1986). Manipulating the anteroposterior pattern of the Drosophila embryo. J. Embryol. exp. Morph. 97 Supplement, 169-179.

Gutzert, H. O. \& Koppa, R. (1982). Time-lapse film analysis of cytoplasmic steaming during late oogenesis of Drosophila. J. Embryol. exp. Morph. 67, 101-111.

GeIGY, R. (1933). Action de l'ultra-violet sur le pole germinal dans l'oeuf de Drosophila melanogaster (castration et mutabilité). Rev. Suisse Zool. 38, 187-288.

IKENISHI, K., NaKazato, S. \& OKada, T. (1986). Direct evidence for the presence of germ cell determinants in vegetal pole cytoplasm of Xenopus laevis and in a subcellular fraction of it. Develop. Growth and Differ. 28, 563-568.

Illmensee, K. \& Mahowald, A. P. (1974). Transplantation of posterior pole plasm in Drosophila. Induction of germ cells at the anterior pole of the egg. Proc. natn. Acad. Sci. U.S.A. 7, 1016-1020.

JAN, L. Y. \& JAN, Y. N. (1982). Antibodies to horseradish peroxidase as specific neuronal markers in Drosophila and in grasshopper embryos. Proc. natn. Acad. Sci. U.S.A. 72, 2700-2704.

JAZDOWSKA-ZAGRODZINSKA, B. (1966). Experimental studies on the role of polar granules in the segregation of pole cells in Drosophila melanogaster. J. Embryol. exp. Morph. 16, 391-399.

KarR, T. L. \& AlberTs, B. M. (1986). Organization of the cytoskeleton in early Drosophila embryos. J. Cell Biol. 102, 1494-1509.

Kessel, R. G. (1981). Origin, distribution and possible functional role of annulate lamellae during spermatogenesis in Drosophila melanogaster. J. Ultrastruct. Res. 75, 72-96.

KING, R. C. (1970). Ovarian Development in Drosophila melanogaster. New York: Academic Press.

LAEMmLI, U. K. (1970). Cleavage of structural proteins during the assembly of the head of bacteriophage $\mathrm{T} 4$. Nature, Lond. 227, 680-685. 
Lehmann, R. \& NUSSlein-Volhard, C. (1986). Abdominal segmentation, pole cell formation, and embryonic polarity require the localized activity of oskar, a maternal gene in Drosophila. Cell 47, 141-152.

LeHMANN, R. \& NüSSLEIN-VolHARD, C. (1987). Involvement of the pumillio gene in the transport of an abdominal signal in the Drosophila embryo. Nature, Lond. 329, 167-170.

Lindsley, D. L. \& Tokuyasu, K. T. (1980). Spermatogenesis. In The Genetics and Biology of Drosophila, vol. 2d (ed. M. Ashburner and T. R. F. Wright), pp. 225-294. New York: Academic Press.

Mahowald, A. P. (1962). Fine structure of pole cells and polar granules in Drosophila melanogaster. J. exp. Zool. 151, 201-216.

Mahowald, A. P. (1968). Polar granules of Drosophila. II. Ultrastructural changes during early embryogenesis. J. exp. Zool. 167, 237-262.

Mahowald, A. P. (1971a). Polar granules of Drosophila. III. The continuity of polar granules during the life cycle of Drosophila. J. exp. Zool. 176, 329-344.

Mahowald, A. P. (1971b). Polar granules of Drosophila. IV. Cytochemical studies showing loss of RNA from polar granules during early stages of embryogenesis. $J$. exp. Zool. 176, 345-352.

Mahowald, A. P. \& Boswell, R. E. (1983). Germ plasm and germ cell development in invertebrates. In Current Problems in Germ Cell Differentiation (ed. A. McLaren \& C. C. Wylie), pp. 3-17. New York: Cambridge University Press.

Mahowald, A. P., Illmensee, K. \& Turner, F. R. (1976). Interspecific transplantation of polar plasm between Drosophila embryos. J. Cell Biol. 70, 358-373.

Mahowald, A. P. \& Kambysellis, M. P. (1978). Oogenesis. In Genetics and Biology of Drosophila, vol. 2d (ed. M. Ashburner \& T. R. F. Wright), pp. 141-224. New York: Academic Press.

Mahowald, A. P. \& Strassheim, J. M. (1970). Intercellular migration of centrioles in the germarium of Drosophila melanogaster. An electron microscopic study. J. Cell Biol. 112, 803-822.

Mohler, J. \& Wieschaus, E. F. (1986). Dominant maternal-effect mutations of Drosophila melanogaster causing the production of double abdomen embryos. Genetics 112, 803-822.

NIKI, Y. (1986). Germline autonomous sterility of the P$M$ dysgenic hybrids and their application to germline transfers in Drosophila melanogaster. Devl Biol. 113, 255-258.

Nusslein-Volhard, C. (1977). Genetic analysis of pattern formation in the embryo of Drosophila melanogaster. Wilhelm Roux's devl Biol. 183, 249-268.

Okada, M., Kleinman, I. A. \& Schneiderman, H. A. (1974). Restoration of fertility in sterilized Drosophila eggs by transplantation of polar cytoplasm. Devl Biol. 37, 43-54.

Oliver, B., Perrimon, N. \& Mahowald, A. P. (1987). The ovo locus is required for sex-specific germ line maintenance in Drosophila. Genes and Development 1, 913-923.

Poulson, D. F. (1950). Histogenesis, organogenesis and differentiation in the embryo of Drosophila melanogaster Meigen. In Biology of Drosophila (ed. M. Demerec), pp. 168-274. New York: Wiley.

Poulson, D. F. \& Waterhouse, D. F. (1960). Experimental studies on pole cells and midgut differentiation in Diptera. Aust. J. biol. Sci. 13, 541-567.

Rabinowtiz, M. (1941). Studies on the cytology and early embryology of the egg of Drosophila melanogaster. $J$. Morph. 69, 1-49.

SchüPBACH, T. \& Wieschaus, E. (1986). Maternal-effect mutations altering the anterior-posterior pattern of the Drosophila embryo. Wilhelm Roux's Arch. devl Biol. 195, 302-317.

SMITH, L. D. (1966). The role of a 'germinal plasm' in the formation of primordial germ cells in Rana pipiens. Devl Biol. 14, 330-347.

Smith, L. D., Michael, P. \& Williams, M. A. (1983). Does a predetermined germ line exist in amphibians? In Current Problems in Germ Cell Differentiation (ed. A. McLaren \& C. C. Wylie), pp. 19-39. New York: Cambridge University Press.

SonNEnblick, B. P. (1941). Germ cell movements and sex differentiation of the gonads in the Drosophila embryo. Proc. natn. Acad. Sci. U.S.A. 27, 484-489.

Sonnenblick, B. P. (1950). The early embryology of Drosophila melanogaster. In Biology of Drosophila (ed. M. Demerec), pp. 62-167. New York: Wiley.

STrome, S. \& Wood, W. B. (1982). Immunofluorescence visualization of germ-line-specific cytoplasmic granules in embryos, larvae, and adults of Caenorhabditis elegans. Proc. natn. Acad. Sci. U.S.A. 79, 1558-1562.

Technau, G. M. \& Campos-Ortega, J. A. (1986). Lineage analysis of transplanted individual cells in embryos of Drosophila melanogaster III. Commitment and proliferative capabilities of pole cells and midgut progenitors. Wilhelm Roux's Arch. devl Biol. 195, $489-498$.

Togashi, S., Koboyashi, S. \& Okada, M. (1986). Functions of maternal mRNA as a cytoplasmic factor responsible for pole cell formation in Drosophila embryos. Devl Biol. 118, 352-360.

Towbin, H., Staehlin, T. \& Gordon, J. (1979). Electrophoretic transfer of proteins from polyacrylamide gels to nitrocellulose sheets: procedures and some applications. Proc. natn. Acad. Sci. U.S.A. 76, 4350-4354.

TuRner, F. R. \& Mahowald, A. P. (1976). Scanning electron microscopy of Drosophila embryogenesis. I. The structure of the egg envelopes and the formation of the cellular blastoderm. Devl Biol. 50, 90-108.

Underwood, E. M., Caulton, J. H., Allis, C. D. \& Mahowald, A. P. (1980). Developmental fate of pole cells in Drosophila melanogaster. Devl Biol. 77, 303-314.

Waring, G. L., Allis, C. D. \& Mahowald, A. P. (1978). Isolation of polar granules and the identification of polar granule specific protein. Devl Biol. 66, 197-206.

WARN, R. (1975). Restoration of the capacity to form pole cells in UV irradiated Drosophila embryos. $J$. 
Embryol. exp. Morph. 33, 1003-1011.

WARN, R. M., SMITH, L. \& WARN, A. (1985). Three distributions of F-actin occur during the divisions of polar surface caps to produce pole cells in Drosophila embryos. J. Cell Biol. 100, 1010-1015.

Weeks, D. L. \& Melton, D. A. (1987). A maternal mRNA localized to the vegetal hemisphere in Xenopus eggs encodes for a growth factor related to TGF- $B$. Cell 51, 861-867.

Zalokar, M. \& ERK, I. (1976). Division and migration of nuclei during early embryogenesis of Drosophila melanogaster. J. Microbiol. Cell. 25, 97-106.

(Accepted 11 April 1988) 